\title{
Pilot Study of Greenhouse Gases and Ammonia Emissions from Naturally Ventilated Barns for Dairy Cows
}

\author{
Wojciech Rzeźnik ${ }^{1 *}$, Paulina Mielcarek, Ilona Rzeźnik² \\ ${ }^{1}$ Institute of Technology and Life Sciences, Biskupińska 67, 60-463 Poznań, Poland \\ ${ }^{2}$ Poznan University of Technology, Berdychowo 4, 61-131 Poznań, Poland
}

Received: 4 April 2016

Accepted: 11 June 2016

\begin{abstract}
In the literature, there are many studies on greenhouse gas and ammonia emissions from dairy barns, however their values are varied. The national inventory of gaseous air pollutants is performed by using theoretical standard emission factors according to the international methodology: Intergovernmental Panel on Climate Change (IPCC) and European Monitoring and Evaluation Programme (EMEP). The aim of the study was to determine the values of greenhouse gases $\left(\mathrm{CH}_{4}, \mathrm{~N}_{2} \mathrm{O}\right)$ and ammonia emission factors during pilot research in commercial barns. The study was conducted in six livestock buildings for dairy cows located in the Wielkopolska Voivodship. The studied barns differed in a construction, the type of resting area and the manure removal system. The 18 daily measurements were made, the 3 test series in each barn. The mean calculated values of greenhouse gases and ammonia emission factors were: $135 \pm 47 \mathrm{~kg} \cdot \mathrm{yr}^{-1} \cdot \mathrm{cow}^{-1}\left(103.4 \pm 35.9 \mathrm{~kg} \cdot \mathrm{yr}^{-1} \cdot \mathrm{LU}^{-1}\right)$ for $\mathrm{CH}_{4}, \quad 0.91 \pm 0.74 \mathrm{~kg} \cdot \mathrm{yr}^{-1} \cdot \mathrm{cow}^{-1}$ $\left(0.70 \pm 0.57 \mathrm{~kg} \cdot \mathrm{yr}^{-1} \cdot \mathrm{LU}^{-1}\right)$ for $\mathrm{N}_{2} \mathrm{O}$ and $8.9 \pm 5.2 \mathrm{~kg} \cdot \mathrm{yr}^{-1} \cdot \mathrm{cow}^{-1}\left(6.9 \pm 3.9 \mathrm{~kg} \cdot \mathrm{yr}^{-1} \cdot \mathrm{LU}^{-1}\right)$ for $\mathrm{NH}_{3}$ The converted on $1 \mathrm{LU}$ (livestock unit $=500 \mathrm{~kg}$ ), $\mathrm{CH}_{4}, \mathrm{~N}_{2} \mathrm{O}$ and $\mathrm{NH}_{3}$ emission factors differed from factors used by National Centre for Emission Management in 2013. The determined factors in this study were lower about $20 \%$ for $\mathrm{CH}_{4}$, higher about $21 \%$ for $\mathrm{N}_{2} \mathrm{O}$ and lower about $67 \%$ for $\mathrm{NH}_{3}$.
\end{abstract}

Keywords: emmision, ammonia, greenhouse gases, dairy cow

\section{Introduction}

Agriculture, mainly livestock production, is a major cause of environmental problems [1-2]. The continuous increase in demand for agricultural products, the development of production technology, and its rising costs have led to the intensification of agriculture. This results in an increase in consolidation of livestock

*e-mail: w.rzeznik@itp.edu.pl production, which creates a number of environmental risks, including the pollution of air, soil, and water. The main air pollutants from agricultural sources are gases such as methane $\left(\mathrm{CH}_{4}\right)$, nitrous oxide $\left(\mathrm{N}_{2} \mathrm{O}\right)$, and ammonia $\left(\mathrm{NH}_{3}\right)$ [3-5]. Greenhouse gases $\left(\mathrm{CH}_{4}, \mathrm{~N}_{2} \mathrm{O}\right)$ contribute to global warming, cause climate change, and reduce the ozone layer in the stratosphere [6-7]. Methane is primarily emitted from enteric fermentation and from animal manure. Nitrous oxide emission is due to crop production as a result of mineral fertilization and less 
from animal manure [8-9]. Ammonia has a local impact and contributes to soil and water acidification, which is hazardous for natural ecosystems [10-13]. Although it is not a greenhouse gas, it indirectly contributes to global warming. During deposition into the soil, $\mathrm{NH}_{3}$ may be converted into $\mathrm{N}_{2} \mathrm{O}$ in nitrification and denitrification processes [14-15].

According to the FAO report "Livestock's Long Shadow: Environmental Issues and Options" [16], agriculture causes $18 \%$ of global anthropogenic emission of greenhouse gases, including: $9 \%$ of $\mathrm{CO}_{2}, 37 \%$ of $\mathrm{CH}_{4}, 65 \%$ of $\mathrm{N}_{2} \mathrm{O}$, and $64 \%$ of $\mathrm{NH}_{3}$ emissions. These values vary depending on the part of the world. However, this calculation also includes deforestation of certain areas of the world to provide feed (mainly grazing cattle). In Poland, the share of agriculture in gas emissions amounted to $77 \%$ for $\mathrm{N}_{2} \mathrm{O}, 32 \%$ for $\mathrm{CH}_{4}$, and $98 \%$ for $\mathrm{NH}_{3}$ in 2013. About $70 \%$ of agricultural $\mathrm{NH}_{3}$ emissions were from animal production. The dairy cattle production sector contributes to $30 \%$ for $\mathrm{NH}_{3}, 58 \%$ for $\mathrm{CH}_{4}$, and $21 \%$ for $\mathrm{N}_{2} \mathrm{O}$ emissions from livestock production [17-18].

The inventory of gaseous air pollutants is performed according to international methodology from the Intergovernmental Panel on Climate Change (IPCC) and the European Monitoring and Evaluation Programme (EMEP). The emissions are estimated on the basis of theoretical factors, so values may differ from those obtained during study in livestock buildings [19]. The literature includes many studies on greenhouse gases and ammonia emissions from dairy barns, but their results are varied. This is due to many factors influencing gas emissions, mainly: animal diet, housing, manure removal systems, weather conditions, and microclimate parameters [20]. One of the difficulties is also the estimation of ventilation rates of the gravity systems commonly used in barns. It is hard to determine ventilation rates as precisely as in buildings with mechanical ventilation. An additional difficulty is the open-frame construction of modern barns, which increases the impact of uncontrolled weather parameters on the emissions of gaseous pollutants [21]. The published values of $\mathrm{CH}_{4}, \mathrm{~N}_{2} \mathrm{O}$, and $\mathrm{NH}_{3}$ emission factors were determined mostly on the basis of measurements in climate chambers [22-23] or in single barns [21-28].

The aim of our study was to determine the values of greenhouse gases $\left(\mathrm{CH}_{4}, \mathrm{~N}_{2} \mathrm{O}\right)$ and ammonia emission factors during pilot research conducted in commercial barns for dairy cows.

Table 1. Specifications of the barns under study.

\begin{tabular}{|c|c|c|c|c|c|}
\hline Barn & $\begin{array}{l}\text { Length/Width/ } \\
\text { Height } \\
(\mathrm{m})\end{array}$ & $\begin{array}{l}\text { Maximum animal } \\
\text { number (cow) }\end{array}$ & $\begin{array}{l}\text { Average annual milk yield } \\
\quad\left(\mathrm{dm}^{3} \cdot \mathrm{cow}^{-1} \cdot \mathrm{year}^{-1}\right)\end{array}$ & Resting area & Manure removal system \\
\hline 1 & $70 / 15 / 3.5$ & 180 & 6,874 & $\begin{array}{l}\text { Collective, } \\
\text { shallow litter }\end{array}$ & $\begin{array}{l}\text { Front-end loader; } \\
\text { every third day }\end{array}$ \\
\hline 2 & $46 / 18 / 5.5$ & 70 & 9,890 & $\begin{array}{c}\text { Rubber matted } \\
\text { stalls }\end{array}$ & $\begin{array}{c}\text { Manure stored under slatted floor; } \\
\text { systematically }\end{array}$ \\
\hline 3 & $60 / 40 / 9$ & 240 & 8,482 & $\begin{array}{l}\text { Collective, } \\
\text { deep litter }\end{array}$ & $\begin{array}{c}\text { Front-end loader (resting area)- } \\
\text { twice a year; delta-scraper (feed and } \\
\text { manure area), } 3 \text { times daily }\end{array}$ \\
\hline 4 & $75 / 32 / 8$ & 240 & 8,637 & Litter stalls & $\begin{array}{l}\text { Delta scraper; } \\
6 \text { times daily }\end{array}$ \\
\hline 5 & $90 / 20 / 7$ & 240 & 10,498 & Litter stalls & $\begin{array}{l}\text { Front-end loader; } \\
\text { once a day }\end{array}$ \\
\hline 6 & $60 / 25 / 10$ & 160 & 8,987 & $\begin{array}{l}\text { Rubber matted } \\
\text { stalls }\end{array}$ & $\begin{array}{l}\text { Manure stored under slatted floor } \\
\text { and robot for systematic removal of } \\
\text { manure }\end{array}$ \\
\hline
\end{tabular}

Table 2. Basic characteristic of daily TMR feed rations.

\begin{tabular}{|c|c|c|c|c|}
\hline Barn & $\begin{array}{c}\text { Mass of ration } \\
\left(\mathrm{kg} \cdot \mathrm{cow}^{-1} \cdot \mathrm{day}^{-1}\right)\end{array}$ & $\begin{array}{c}\text { Dry matter content } \\
(\%)\end{array}$ & $\begin{array}{c}\text { Crude protein content } \\
(\% \mathrm{DM})\end{array}$ & $\begin{array}{c}\text { Concentration of metabolic energy } \\
\left(\mathrm{MJ} \cdot \mathrm{NEL}^{-1} \cdot \mathrm{kg}^{-1}\right)\end{array}$ \\
\hline 1 & 43.9 & 43.4 & 15.7 & 6.5 \\
\hline 2 & 52.3 & 46.2 & 16.3 & 7.0 \\
\hline 3 & 45.6 & 44.1 & 15.9 & 6.8 \\
\hline 4 & 46.3 & 44.3 & 16.1 & 6.8 \\
\hline 5 & 53.1 & 45.6 & 16.7 & 7.1 \\
\hline 6 & 45.8 & 47.2 & 15.6 & 6.7 \\
\hline
\end{tabular}




\section{Materials and Methods}

\section{Researched Barns}

The study was conducted in six livestock buildings for dairy cows located in Wielkopolska Voivodship. The main criterion for selecting the barns was the housing system. In the selected objects dairy cows were kept in commonly used or perspective housing systems in Poland. All of them were free-stall barns, with one modernized facility (barn 1 ), one traditional building (barn 2), and four new frame constructions (barns 3-6) (Fig. 1). The studied buildings were ventilated by gravity systems. In barns 3-6 fresh air was provided by partial sidewall openings controlled by curtains and removed through open ridges. The ventilation systems were supported by cooling circulation fans. Barns 1 and 2 were buildings of traditional construction with solid concrete sidewalls with windows that could be opened. The air exchange was provided by those windows and through the open ridge in barn 2 and through the chimney vents in barn 1 . The barns differed also in the type of their resting area, manure removal systems and TMR feed rations (Table 1 and 2).

Temperature, Relative Humidity, and Gas Concentrations

The three test series were made in each barn: the first during April and May, the second during July, and the last one during November and December. The study included 18 daily measurements in total. Measurements of the greenhouse gases $\left(\mathrm{CH}_{4}, \mathrm{~N}_{2} \mathrm{O}\right.$, and $\left.\mathrm{CO}_{2}\right)$ and ammonia $\left(\mathrm{NH}_{3}\right)$ concentrations were made outside and inside the building by a Multi-Gas Monitor Innova 1312 photo-acoustic spectrometer. The lower detection limit of measuring was: $0.06 \mathrm{mg} \cdot \mathrm{m}^{-3}(0.03 \mathrm{ppm})$ for $\mathrm{N}_{2} \mathrm{O}$, $0.28 \mathrm{mg} \cdot \mathrm{m}^{-3}(0.4 \mathrm{ppm})$ for $\mathrm{CH}_{4}, 9.89 \mathrm{mg} \cdot \mathrm{m}^{-3}(5.1 \mathrm{ppm})$ for $\mathrm{CO}_{2}$, and $0.15 \mathrm{mg} \cdot \mathrm{m}^{-3}(0.2 \mathrm{ppm})$ for $\mathrm{NH}_{3}$. The multigas monitor was equipped with filters: type UA 0985 for $\mathrm{N}_{2} \mathrm{O}$, type UA 0969 for $\mathrm{CH}_{4}$, type UA 0983 for $\mathrm{CO}_{2}$, and
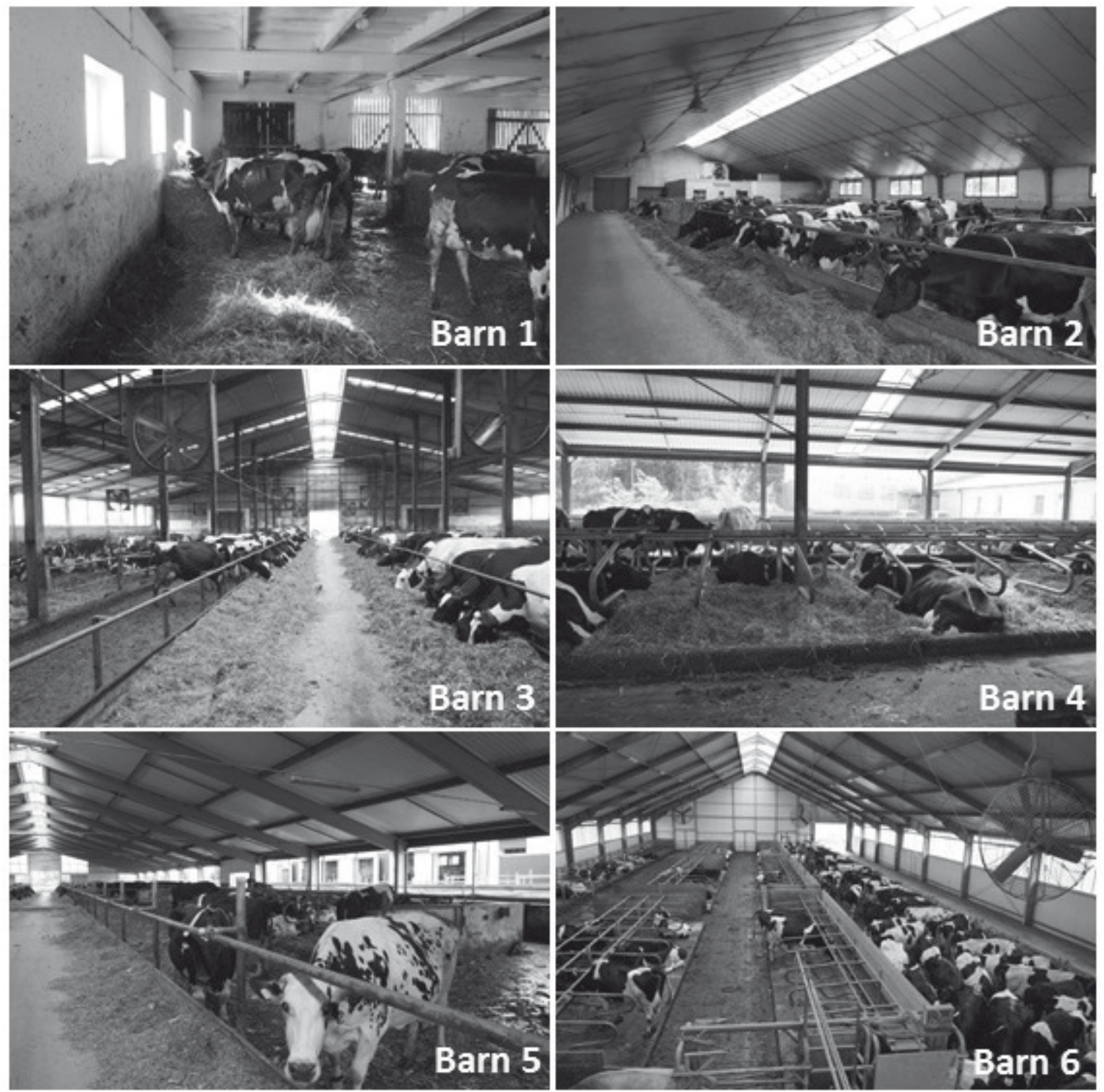

Fig. 1. The insides of studied barns. 
type UA 0976 for $\mathrm{NH}_{3}$. Temperature and relative humidity of air inside the buildings were recorded using a Testo $175 \mathrm{H} 2$ logger with $0.5^{\circ} \mathrm{C}$ and $3 \%$ accuracy. The outside concentration of gases was measured at one point located at a minimum distance of $10 \mathrm{~m}$ from the windward side of the building, at the height of inlets in the half-opened side walls (about $2 \mathrm{~m}$ ). The selection of the location of a measurement point inside barns was preceded by measurements of a few points inside each barn. The differences in gas concentration values in a central point and the other points did not exceed $10 \%$, so daily measurements were carried out at one point located in the central part of the buildings at half of total barn height (Fig. 2). The results of gas concentration measurements at that point were considered representative for the barn. In barn 1, where the air was removed by chimney ducts, concentrations were measured at the inlet of the chimney duct located in the central part of the building. That choice was made on the basis of preliminary measurements of concentrations at the inlets of all ducts. The same location in each barn also monitored temperature and relative humidity. The concentration of gases, temperature, and relative humidity were measured every hour.

\section{Ventilation Rate and Gas Emissions}

The ventilation rate was determined according to CIGR methodology [29], which is based on a comparison of the carbon dioxide $\left(\mathrm{CO}_{2}\right)$ concentrations inside and outside the building. It assumes that $\mathrm{CO}_{2}$ is produced mainly by animals, and minimally comes from manure, slurry, or other sources, and that the air throughout livestock buildings is perfectly mixed. Taking this into account, the difference between the concentrations of $\mathrm{CO}_{2}$ inside and outside the building results from the rate of its production, and thus the ventilation rate [30-31]. Ventilation rate VR $\left(\mathrm{m}^{3} \cdot \mathrm{h}^{-1}\right)$ was calculated from equation $(1)$ :

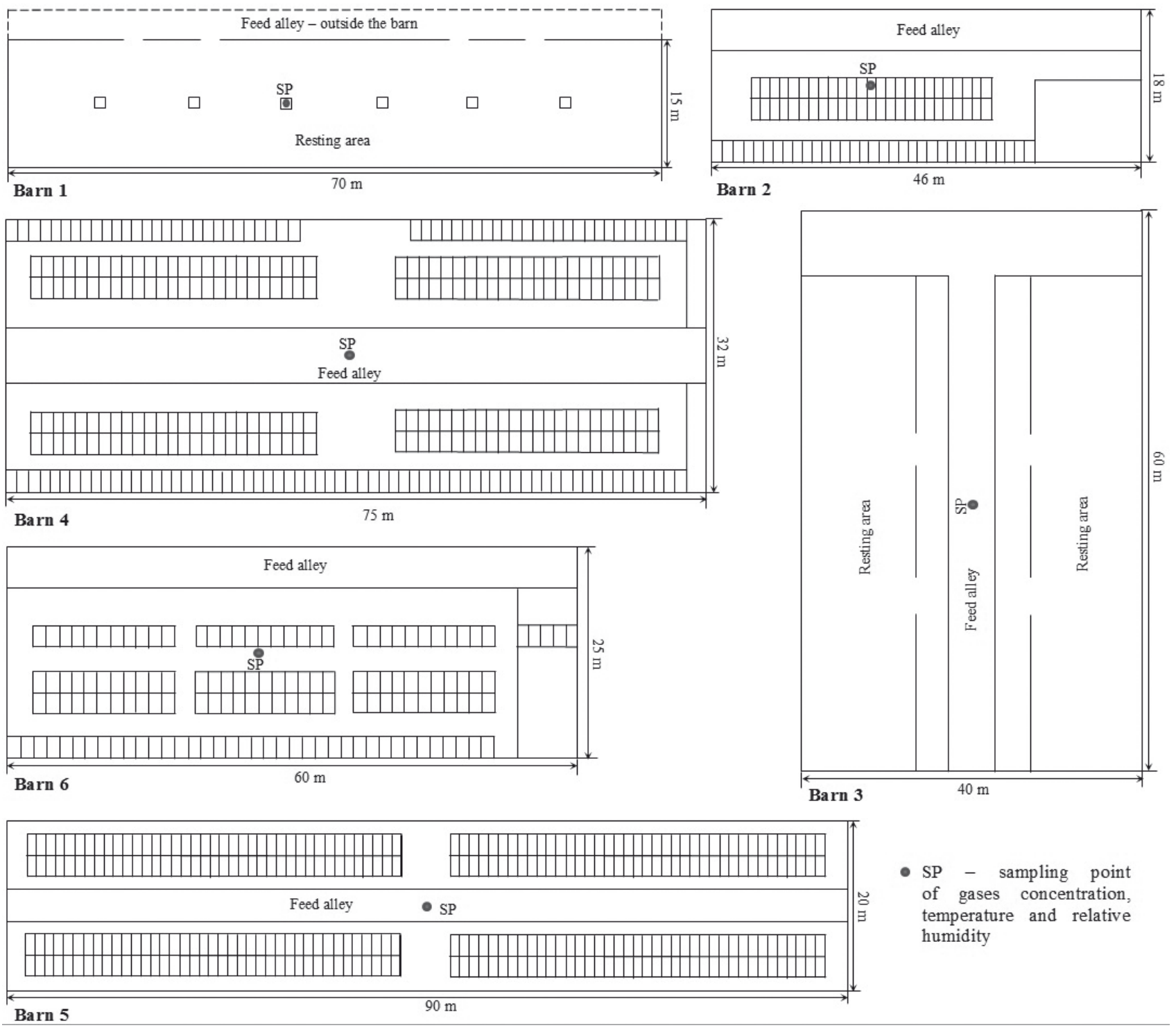

Fig. 2. Location of sampling point in studied barns. 


$$
V R=\frac{n \cdot P_{\mathrm{CO}_{2}}}{C_{\text {in }}-C_{\text {out }}}
$$

...where $n$ is the number of cows, $P_{\mathrm{CO}_{2}}$ is the amount of $\mathrm{CO}_{2}$ emitted by one cow $\left(\mathrm{mg} \cdot \mathrm{h}^{-1} \cdot \mathrm{cow}^{-1}\right), C_{\text {in }}$ is $\mathrm{CO}_{2}$ concentration inside the building $\left(\mathrm{mg} \cdot \mathrm{m}^{-3}\right)$, and $C_{\text {out }}$ is $\mathrm{CO}_{2}$ concentration outside the building $\left(\mathrm{mg} \cdot \mathrm{m}^{-3}\right)$.

In order to calculate the amount of carbon dioxide $P_{\mathrm{CO} 2}$ excreted by one cow, it is necessary to calculate the heat production which is required for life maintenance $q_{l}(\mathrm{~W})$, for pregnancy $q_{p}(\mathrm{~W})$, and milk production $q_{m}(\mathrm{~W})$. These values were calculated according to equations (2), (3), and (4):

$$
\begin{gathered}
q_{l}=5,6 \cdot m^{0,75} \\
q_{p}=1,6 \cdot 10^{-5} \cdot p^{3}
\end{gathered}
$$

$$
q_{m}=22 \cdot y
$$

...where $m$ is cow mass $(\mathrm{kg}), p$ is number of days after insemination (day), and $y$ is milk yield $\left(\mathrm{kg} \cdot \mathrm{day}^{-1}\right)$.

Values $p, m$, and $y$, which are necessary to calculate the heat, were collected from the database of electronic herd management systems. The total heat produced by animals $q_{t}(\mathrm{~W})$ is the sum of the above-mentioned quantities. Value $q_{t}$ refers to the inside barn temperature, which is equal to $20^{\circ} \mathrm{C}$, whereas the heat varies with temperature. It was necessary to calculate the corrected value $q_{\text {kor }}$ (W) from equation (5):

$$
q_{\text {cor }}=q_{t} \cdot C F
$$

...where $C F$ is the correction factor, which includes inside temperature $t_{\text {in }}\left({ }^{\circ} \mathrm{C}\right)$ and is described with the following equation 6):

Table 3. Microclimate parameter data and mean greenhouse gases and ammonia concentrations.

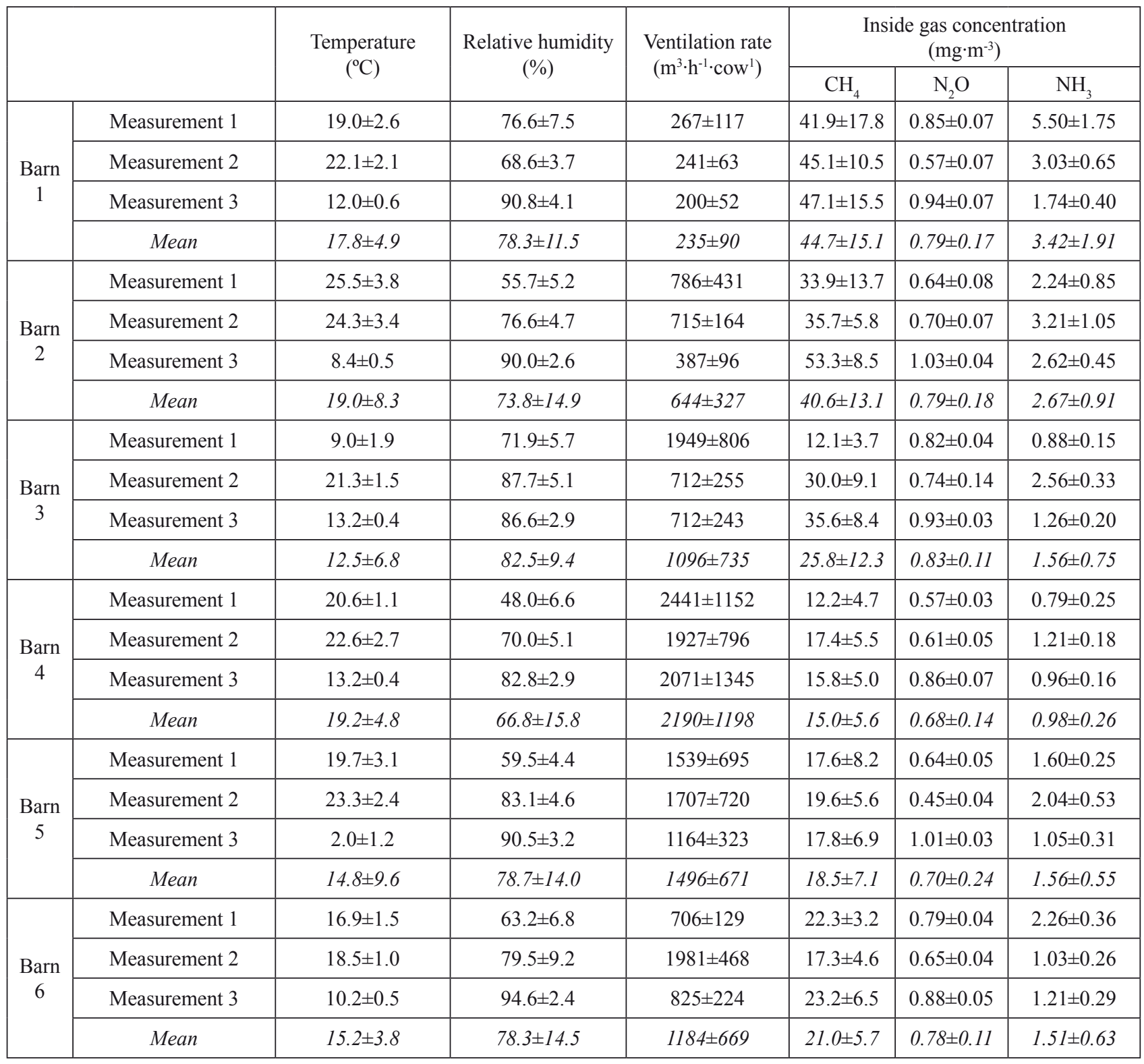


Table 4. Mean daily emission factors of greenhouse gases and ammonia.

\begin{tabular}{|c|c|c|c|c|c|c|c|}
\hline & & \multicolumn{6}{|c|}{ Mean daily emission factor } \\
\hline & & \multicolumn{2}{|c|}{$\mathrm{CH}_{4}$} & \multicolumn{2}{|c|}{$\mathrm{N}_{2} \mathrm{O}$} & \multicolumn{2}{|c|}{$\mathrm{NH}_{3}$} \\
\hline & & $\left(g \cdot h^{-1} \cdot \operatorname{cow}^{-1}\right)$ & $\left(\mathrm{g} \cdot \mathrm{h}^{-1} \cdot \mathrm{LU}^{-1}\right)$ & $\left(\mathrm{g} \cdot \mathrm{h}^{-1} \cdot \operatorname{cow}^{-1}\right)$ & $\left(g \cdot h^{-1} \cdot L^{-1}\right)$ & $\left(\mathrm{g} \cdot \mathrm{h}^{-1} \cdot \operatorname{cow}^{-1}\right)$ & $\left(g \cdot h^{-1} \cdot L^{-1}\right)$ \\
\hline \multirow{4}{*}{$\begin{array}{c}\text { Barn } \\
1\end{array}$} & Measurement 1 & $8.6 \pm 1.5$ & $6.6 \pm 1.2$ & $0.015 \pm 0.009$ & $0.012 \pm 0.007$ & $1.20 \pm 0.31$ & $0.92 \pm 0.24$ \\
\hline & Measurement 2 & $8.1 \pm 0.6$ & $6.2 \pm 0.5$ & $0.031 \pm 0.018$ & $0.024 \pm 0.014$ & $0.52 \pm 0.20$ & $0.40 \pm 0.15$ \\
\hline & Measurement 3 & $8.4 \pm 0.6$ & $6.5 \pm 0.5$ & $0.027 \pm 0.015$ & $0.021 \pm 0.012$ & $0.32 \pm 0.14$ & $0.25 \pm 0.11$ \\
\hline & Mean & $8.3 \pm 1.1$ & $6.4 \pm 0.8$ & $0.025 \pm 0.016$ & $0.019 \pm 0.012$ & $0.67 \pm 0.42$ & $0.52 \pm 0.32$ \\
\hline \multirow{4}{*}{$\begin{array}{c}\text { Barn } \\
2\end{array}$} & Measurement 1 & $16.2 \pm 1.8$ & $12.5 \pm 1.38$ & $0.149 \pm 0.087$ & $0.115 \pm 0.067$ & $0.95 \pm 0.21$ & $0.73 \pm 0.16$ \\
\hline & Measurement 2 & $14.9 \pm 1.7$ & $11.5 \pm 1.3$ & $0.165 \pm 0.057$ & $0.127 \pm 0.044$ & $1.57 \pm 0.55$ & $1.21 \pm 0.42$ \\
\hline & Measurement 3 & $19.4 \pm 4.0$ & $14.9 \pm 3.1$ & $0.089 \pm 0.022$ & $0.068 \pm 0.017$ & $0.78 \pm 0.38$ & $0.60 \pm 0.29$ \\
\hline & Mean & $17.0 \pm 3.4$ & $13.1 \pm 2.6$ & $0.139 \pm 0.072$ & $0.107 \pm 0.055$ & $1.10 \pm 0.51$ & $0.85 \pm 0.39$ \\
\hline \multirow{4}{*}{$\begin{array}{c}\text { Barn } \\
3\end{array}$} & Measurement 1 & $15.9 \pm 2.4$ & $12.2 \pm 1.8$ & $0.087 \pm 0.052$ & $0.067 \pm 0.040$ & $0.66 \pm 0.36$ & $0.51 \pm 0.28$ \\
\hline & Measurement 2 & $11.1 \pm 2.3$ & $8.5 \pm 1.8$ & $0.199 \pm 0.078$ & $0.153 \pm 0.060$ & $1.30 \pm 0.37$ & $1.00 \pm 0.28$ \\
\hline & Measurement 3 & $22.9 \pm 2.8$ & $17.6 \pm 2.2$ & $0.088 \pm 0.031$ & $0.068 \pm 0.024$ & $0.50 \pm 0.11$ & $0.38 \pm 0.08$ \\
\hline & Mean & $16.7 \pm 5.6$ & $12.8 \pm 4.3$ & $0.127 \pm 0.080$ & $0.098 \pm 0.062$ & $0.79 \pm 0.45$ & $0.61 \pm 0.35$ \\
\hline \multirow{4}{*}{$\begin{array}{c}\text { Barn } \\
4\end{array}$} & Measurement 1 & $17.9 \pm 2.0$ & $13.8 \pm 1.5$ & $0.093 \pm 0.061$ & $0.072 \pm 0.047$ & $0.83 \pm 0.30$ & $0.64 \pm 0.23$ \\
\hline & Measurement 2 & $16.3 \pm 5.1$ & $12.5 \pm 3.9$ & $0.171 \pm 0.099$ & $0.131 \pm 0.076$ & $1.02 \pm 0.37$ & $0.78 \pm 0.28$ \\
\hline & Measurement 3 & $19.8 \pm 5.5$ & $15.2 \pm 4.2$ & $0.179 \pm 0.078$ & $0.138 \pm 0.060$ & $1.13 \pm 0.66$ & $0.87 \pm 0.51$ \\
\hline & Mean & $18.1 \pm 5.0$ & $13.9 \pm 3.8$ & $0.150 \pm 0.093$ & $0.115 \pm 0.072$ & $1.00 \pm 0.51$ & $0.77 \pm 0.39$ \\
\hline \multirow{4}{*}{$\begin{array}{c}\text { Barn } \\
5\end{array}$} & Measurement 1 & $15.4 \pm 2.5$ & $11.8 \pm 1.9$ & $0.201 \pm 0.084$ & $0.155 \pm 0.065$ & $1.49 \pm 0.54$ & $1.15 \pm 0.42$ \\
\hline & Measurement 2 & $12.4 \pm 3.4$ & $9.5 \pm 2.6$ & $0.129 \pm 0.080$ & $0.099 \pm 0.062$ & $1.99 \pm 0.63$ & $1.53 \pm 0.48$ \\
\hline & Measurement 3 & $18.3 \pm 3.7$ & $14.1 \pm 2.8$ & $0.049 \pm 0.027$ & $0.038 \pm 0.021$ & $1.17 \pm 0.62$ & $0.90 \pm 0.48$ \\
\hline & Mean & $15.4 \pm 4.2$ & $11.8 \pm 3.2$ & $0.124 \pm 0.094$ & $0.095 \pm 0.072$ & $1.56 \pm 0.71$ & $1.20 \pm 0.55$ \\
\hline \multirow{4}{*}{$\begin{array}{c}\text { Barn } \\
6\end{array}$} & Measurement 1 & $12.9 \pm 0.7$ & $9.9 \pm 0.5$ & $0.033 \pm 0.022$ & $0.025 \pm 0.017$ & $1.30 \pm 0.31$ & $1.00 \pm 0.24$ \\
\hline & Measurement 2 & $20.4 \pm 6.3$ & $15.7 \pm 4.8$ & $0.103 \pm 0.071$ & $0.079 \pm 0.055$ & $0.97 \pm 0.51$ & $0.75 \pm 0.39$ \\
\hline & Measurement 3 & $17.2 \pm 1.2$ & $13.2 \pm 0.9$ & $0.053 \pm 0.030$ & $0.041 \pm 0.023$ & $0.67 \pm 0.24$ & $0.52 \pm 0.18$ \\
\hline & Mean & $16.8 \pm 4.9$ & $12.9 \pm 3.8$ & $0.062 \pm 0.054$ & $0.048 \pm 0.042$ & $0.98 \pm 0.46$ & $0.75 \pm 0.35$ \\
\hline
\end{tabular}

$$
C F=4 \cdot 10^{-5} \cdot\left(20-t_{\text {in }}\right)^{3}+1
$$

The amount of $\mathrm{CO}_{2} P_{\mathrm{CO} 2}\left(\mathrm{mg} \cdot \mathrm{h}^{-1} \cdot \mathrm{cow}^{-1}\right)$ excreted by one cow was calculated according to the following equation (7) $[32-33]$ :

$$
P_{\mathrm{Co}_{2}}=299 \cdot q_{\mathrm{cor}}
$$

The greenhouse gases and ammonia emission $E\left(\mathrm{~g} \cdot \mathrm{h}^{-1}\right)$ from studied barns was calculated, as the product of the difference in the concentration of gases inside $C_{\text {in }}$ $\left(\mathrm{mg} \cdot \mathrm{m}^{-3}\right)$, outside $C_{\text {out }}\left(\mathrm{mg} \cdot \mathrm{m}^{-3}\right)$, and the ventilation rate $V R$ according to equation (8):

$$
E=V R \cdot\left(C_{\text {in }}-C_{\text {out }}\right) \cdot 10^{-3}
$$

The gas emission factors $E F\left(\mathrm{~g} \cdot \mathrm{h}^{-1} \cdot \mathrm{cow}^{1}\right)$ were expressed depending on the number of cows in the barn. The average mass of one cow was determined based on the culling cows documentation. The mean mass was $650 \mathrm{~kg}$ in all barns.

\section{Results and Discussion}

The mean daily inside and outside concentrations of measured gases and mean daily ventilation rates are shown in Table 3.

The variability of $\mathrm{CH}_{4}$ and $\mathrm{NH}_{3}$ concentrations inside the barns was higher than outdoors. Only for $\mathrm{N}_{2} \mathrm{O}$ was it comparable. The mean daily concentrations of greenhouse gases and ammonia were characterized by low (for $\mathrm{N}_{2} \mathrm{O}$ ) 
Table 5. The published emission factors of $\mathrm{CH}_{4}, \mathrm{~N}_{2} \mathrm{O}$, and $\mathrm{NH}_{3}$ expressed in $\mathrm{g} \cdot \mathrm{h}^{-1} \cdot \mathrm{LU}^{-1}$.

\begin{tabular}{|c|c|c|c|c|c|}
\hline \multirow[t]{2}{*}{ Housing system } & \multirow[t]{2}{*}{ Manure removal system } & \multicolumn{3}{|c|}{$\begin{array}{l}\text { Emission factor } \\
\left(\mathrm{g} \cdot \mathrm{h}^{-1} \cdot \mathrm{LU}^{-1}\right)\end{array}$} & \multirow[t]{2}{*}{ Source } \\
\hline & & $\mathrm{CH}_{4}$ & $\mathrm{~N}_{2} \mathrm{O}$ & $\mathrm{NH}_{3}$ & \\
\hline $\begin{array}{c}\text { Free-stall non-litter barns; } \\
\text { cubicles with sawdust-filled rubber } \\
\text { mattresses }\end{array}$ & $\begin{array}{l}\text { Manure was removed by flushing the alleys three } \\
\text { times per day }\end{array}$ & 12.1 & 0.029 & & {$[24]$} \\
\hline Free-stall non-litter barn; cubicles & $\begin{array}{l}\text { Manure stored under slatted floor; scraped twice } \\
\text { a day }\end{array}$ & 11.4 & & 0.89 & {$[21]$} \\
\hline $\begin{array}{l}\text { Free-stall non-litter barn; } \\
\text { cubicles with rubber mattresses } \\
\text { covered with a peat }\end{array}$ & $\begin{array}{l}\text { The solid concrete floor scraped } 18 \text { times per day; } \\
\text { The slurry was dumped into a partly covered pit } \\
\text { emptied one time per day }\end{array}$ & 10.8 & & 0.81 & {$[36]$} \\
\hline \multirow[t]{2}{*}{ Free-stall barn; cubicles } & $\begin{array}{l}\text { Slatted floor with subfloor storage and with ho- } \\
\text { mogenization }\end{array}$ & $13.5-15.9$ & & $1.2-1.6$ & \multirow[t]{2}{*}[37]{} \\
\hline & Solid floor scraped 20 times per day & 14.7 & & 1.5 & \\
\hline $\begin{array}{l}\text { Free-stall open-lot barn; } \\
\text { pens }\end{array}$ & $\begin{array}{l}\text { Manure was scraped and piled in the pens or vacu- } \\
\text { umed from feed alleys daily and placed into cells } \\
\text { near the solid separator }\end{array}$ & 16.1 & 0.328 & 4.2 & {$[26]$} \\
\hline Free-stall barn; cubicles & Slatted floor with automatic scraper & & & & [34] \\
\hline Free-stall barn; cubicles & $\begin{array}{l}\text { The manure was scraped } \\
\text { to the outside manure storage }\end{array}$ & & & & [34] \\
\hline $\begin{array}{l}\text { Free-stall barn; collective floor } \\
\text { with shallow straw litter }\end{array}$ & $\begin{array}{l}\text { The manure was scraped to the dunging passage } \\
\text { and then transported by a wheel loader to the } \\
\text { outside manure storage }\end{array}$ & & & & [34] \\
\hline Free-stall barn; cubicles & Slatted floor & & & & [34] \\
\hline Free-stall non-litter barn; cubicles & Slatted floor with dung channel & $5.9-11.3$ & & $0.2-0.8$ & [35] \\
\hline $\begin{array}{c}\text { Free-stall litter barns; } \\
\text { cubicles with straw mattresses }\end{array}$ & $\begin{array}{l}\text { Solid floor cleaned three or four times a day with } \\
\text { scraper }\end{array}$ & & & $0.3-2.8$ & {$[38]$} \\
\hline
\end{tabular}

and medium (for $\mathrm{CH}_{4}$ and $\mathrm{NH}_{3}$ ) diurnal variations. Those differences were due to ventilation rate values which were dependent on weather conditions. The gas concentrations also differed between studied facilities. The statistical analysis (Kruskal-Wallis test and multiple comparisons of mean ranks for all groups) showed the statistically significant differences in $\mathrm{CH}_{4}$ and $\mathrm{NH}_{3}$ concentrations between studied barns. The $\mathrm{CH}_{4}$ and $\mathrm{NH}_{3}$ mean concentrations were higher in barns 1 and 2 than in other buildings $(\mathrm{p} \leq 0.05)$. This may be due to their construction, which limited free air flow more than in other objects. The mean $\mathrm{NH}_{3}$ concentration in barn 4 was the lowest and differed

Table 6. The published emission factors of $\mathrm{CH}_{4}, \mathrm{~N}_{2} \mathrm{O}$, and $\mathrm{NH}_{3}$ expressed in $\mathrm{g} \cdot \mathrm{h}^{-1} \cdot \mathrm{cow}^{-1}$.

\begin{tabular}{|c|c|c|c|c|c|}
\hline \multirow[t]{2}{*}{ Housing system } & \multirow[t]{2}{*}{ Manure removal system } & \multicolumn{3}{|c|}{$\begin{array}{l}\text { Emission factor } \\
\left(\mathrm{g} \cdot \mathrm{h}^{-1} \cdot \mathrm{cow}^{-1}\right)\end{array}$} & \multirow[t]{2}{*}{ Source } \\
\hline & & $\mathrm{CH}_{4}$ & $\mathrm{~N}_{2} \mathrm{O}$ & $\mathrm{NH}_{3}$ & \\
\hline $\begin{array}{l}\text { Free-stall deep litter barn; } \\
\text { collective floor }\end{array}$ & $\begin{array}{l}\text { Manure removed once or twice a year; slatted floor } \\
\text { close to feed-alley }\end{array}$ & $29.2-37.5$ & 0.075 & $1.3-1.4$ & {$[27]$} \\
\hline Tie-stall litter barn; cubicles & Solid floor; manure was removed systematically & 11.3 & 0.145 & 0.24 & [39] \\
\hline $\begin{array}{l}\text { Free-stall litter barn; } \\
\text { cubicles with straw }\end{array}$ & Solid floor; manure scraped every day & & & 4.6 & [40] \\
\hline Tie-stall non-litter barn; cubicles & Solid floor; manure scraped two times per day & & & 1.21 & [41] \\
\hline $\begin{array}{l}\text { Free-stall litter barn; } \\
\text { cubicles with straw }\end{array}$ & Solid floor; manure scraped two times per day & & & 0.71 & [41] \\
\hline $\begin{array}{l}\text { Free-stall non-litter barn; } \\
\text { cubicles }\end{array}$ & $\begin{array}{l}\text { Partly slatted floor; manure from the closed canals } \\
\text { was removed three times per year }\end{array}$ & & & 1.21 & [41] \\
\hline $\begin{array}{l}\text { Tie-stall litter barns; cubicles with } \\
\text { wood-shavings and straw }\end{array}$ & $\begin{array}{l}\text { Solid floor; manure was transported to a storage by } \\
\text { chain conveyors and then an outside storage tank }\end{array}$ & & & $0.2-0.8$ & {$[42]$} \\
\hline
\end{tabular}


statistically significantly from other objects, which may be the result of the highest ventilation rate in this barn. The analysis did not show the difference in $\mathrm{NH}_{3}$ concentration between barns 3,5 , and $6(\mathrm{p} \leq 0.05)$.

The statistical analysis showed the statistically significant differences for mean $\mathrm{N}_{2} \mathrm{O}$ concentrations between barn 4 and other buildings $(p \leq 0.05)$. The lowest concentration of this gas in barn 4 may be due to the highest ventilation rate, but other factors like manure removal or housing systems may also be affected. During the study the lowest and highest measured concentrations of gases were $7.27 \mathrm{mg} \cdot \mathrm{m}^{-3}$ (barn 5) and $92.09 \mathrm{mg} \cdot \mathrm{m}^{-3}$ (barn 1) for $\mathrm{CH}_{4}, 0.38 \mathrm{mg} \cdot \mathrm{m}^{-3}$ (barn 5) and $1.11 \mathrm{mg} \cdot \mathrm{m}^{-3}$ (barn 2) for $\mathrm{N}_{2} \mathrm{O}$, and $0.47 \mathrm{mg} \cdot \mathrm{m}^{-3}$ (barn 5) and $8.24 \mathrm{mg} \cdot \mathrm{m}^{-3}$ (barn 1) for $\mathrm{NH}_{3}$. The measured gas concentrations were similar to results of other published papers on this subject. Snell et al. [34] reported $\mathrm{NH}_{3}$ concentrations of 3.9 to $8.9 \mathrm{mg} \cdot \mathrm{m}^{-3}$ and for $\mathrm{CH}_{4}$ from 35.2 to $62.3 \mathrm{mg} \cdot \mathrm{m}^{-3}$, whereas Ngwabie et al. [21] observed a range of concentrations: $1.3-13.5 \mathrm{mg} \cdot \mathrm{m}^{-3}$ for $\mathrm{NH}_{3}, 0.31-1.46 \mathrm{mg} \cdot \mathrm{m}^{-3}$ for $\mathrm{N}_{2} \mathrm{O}$, and 6.4-199.8 $\mathrm{mg} \cdot \mathrm{m}^{-3}$ for $\mathrm{CH}_{4}$. The comparable results obtained by Rong et al. [35] were 0.3-11.6 $\mathrm{mg} \cdot \mathrm{m}^{-3}$ for $\mathrm{NH}_{3}$, $0.37-1.61 \mathrm{mg} \cdot \mathrm{m}^{-3}$ for $\mathrm{N}_{2} \mathrm{O}$, and $1.5-154.9 \mathrm{mg} \cdot \mathrm{m}^{-3}$ for $\mathrm{CH}_{4}$.

The mean daily emission factors of greenhouse gases and ammonia for studied barns related to one cow and to $1 \mathrm{LU}$ (livestock unit $=500 \mathrm{~kg}$ ) are presented in Table 4.

The calculated emission factors for studied gases were statistically analyzed. The Kruskal-Wallis test and multiple comparisons of mean ranks for all groups were made to show the differences between barns. The lowest emission factor of $\mathrm{NH}_{3}$, which differed statistically significantly from almost all studied barns (expect barn 3), was noted in barn $1(\mathrm{p} \leq 0.05)$. This may be the result of the lowest ventilation rate in this building. The value of ammonia emission factor for barn 3 was also low and the differences were proved with barns 2 and $5(\mathrm{p} \leq 0.05)$. The reason may be quite a low ventilation rate and the high-quality bedding material (rye straw replaced every two days). The highest emission factor of $\mathrm{NH}_{3}$ which differed statistically significantly from all studied barns, was in barn 5 $(p \leq 0.05)$, which may be due to the high ventilation rate, the type of manure removal system, and the low-quality bedding material (corn stover). The $\mathrm{N}_{2} \mathrm{O}$ emission factors for barns 1 and 6 differed statistically significantly from other buildings ( $\mathrm{p} \leq 0.05)$. The lowest values in these buildings had different causes. In barn 1 it may be the much lower ventilation rate than in other barns. For barn 6 the low $\mathrm{N}_{2} \mathrm{O}$ emission factor may be the effect of many factors: a non-litter housing system and using robots for systematic removal of manure. For $\mathrm{CH}_{4}$ the statistically significant differences were seen only between barn 1 and other buildings ( $\mathrm{p} \leq 0.05$ ), which may be caused by the low ventilation rate.

The value of $\mathrm{CH}_{4}$ emission factors determined as the mean hourly for all measurement days (for all barns) was $15.4 \mathrm{~g} \cdot \mathrm{h}^{-1} \cdot \mathrm{cow}^{-1}\left(11.8 \mathrm{~g} \cdot \mathrm{h}^{-1} \cdot \mathrm{LU}^{-1}\right)$. The minimum momentary factor value was equal to $1.7 \mathrm{~g} \cdot \mathrm{h}^{-1} \cdot \mathrm{cow}^{-1}$ (1.3 $\left.\mathrm{g} \cdot \mathrm{h}^{-1} \cdot \mathrm{LU}^{-1}\right)$ and the maximum amounted to
$40.6 \mathrm{~g} \cdot \mathrm{h}^{-1} \cdot \mathrm{cow}^{-1}\left(31.2 \mathrm{~g} \cdot \mathrm{h}^{-1} \cdot \mathrm{LU}^{-1}\right)$ with medium variation over the whole period (coefficient of variation 34\%).

The $\mathrm{N}_{2} \mathrm{O}$ emission factor calculated in this study was $0.10 \mathrm{~g} \cdot \mathrm{h}^{-1} \cdot \mathrm{cow}^{-1}\left(0.080 \mathrm{~g} \cdot \mathrm{h}^{-1} \cdot \mathrm{LU}^{-1}\right)$. The fluctuations of momentary factor values were very high (coefficient of variation $82 \%$ ) - from a minimum of $0.002 \mathrm{~g} \cdot \mathrm{h}^{-1} \cdot \mathrm{cow}^{-1}$ $\left(0.002 \mathrm{~g} \cdot \mathrm{h}^{-1} \cdot \mathrm{LU}^{-1}\right)$ to a maximum of $0.437 \mathrm{~g} \cdot \mathrm{h}^{-1} \cdot \mathrm{cow}^{-1}$ $\left(0.336 \mathrm{~g} \cdot \mathrm{h}^{-1} \cdot \mathrm{LU}^{-1}\right)$. The $\mathrm{NH}_{3}$ emission factor obtained as a mean value of all results was $1.02 \mathrm{~g} \cdot \mathrm{h}^{-1} \cdot \mathrm{cow}^{-1}$ $\left(0.79 \mathrm{~g} \cdot \mathrm{h}^{-1} \cdot \mathrm{LU}^{-1}\right)$, and it was characterized by high variability (coefficient of variation 58\%). The momentary $\mathrm{NH}_{3}$ emission factor value ranged from 0.11 to $3.47 \mathrm{~g} \cdot \mathrm{h}^{-1} \cdot \operatorname{cow}^{-1}\left(0.08-2.67 \mathrm{~g} \cdot \mathrm{h}^{-1} \cdot \mathrm{LU}^{-1}\right)$. The $\mathrm{CH}_{4}, \mathrm{~N}_{2} \mathrm{O}$ and $\mathrm{NH}_{3}$ emission factors calculated during this study are similar to published values presented in Tables 5 and 6 .

Reports of Polish greenhouse gas and ammonia emissions are based on standard factors. To compare them with results of this study, the average emission factor was calculated from all 18 measurement days for each studied gas, and it was expressed in $\mathrm{kg} \cdot \mathrm{yr}^{-1} \cdot \mathrm{LU}^{-1}$. Reports from the National Centre for Emission Management (KOBIZE) [17] assumed the mass of a cow as $500 \mathrm{~kg}$ (1 LU). For $\mathrm{CH}_{4}$, emission factors are calculated according to the recommendations of IPCC methodology [14]. The total was $128.8 \mathrm{~kg} \cdot \mathrm{yr}^{-1} \cdot \mathrm{LU}^{-1}$ in 2013 year (enteric fermentation of $117.4 \mathrm{~kg} \cdot \mathrm{yr}^{-1} \cdot \mathrm{LU}^{-1}$ and manure management of 11.4 $\left.\mathrm{kg} \cdot \mathrm{yr}^{-1} \cdot \mathrm{LU}^{-1}\right)$ [17]. The $\mathrm{CH}_{4}$ emission factor determined in this study $\left(103.4 \mathrm{~kg} \cdot \mathrm{yr}^{-1} \cdot \mathrm{LU} \mathrm{kg}^{-1}\right)$ was $20 \%$ lower than calculated by KOBIZE [17]. The factor calculated during this study for $\mathrm{N}_{2} \mathrm{O}\left(0.70 \mathrm{~kg} \cdot \mathrm{yr}^{-1} \cdot \mathrm{LU}^{-1}\right)$ was $21 \%$ higher than the $\mathrm{N}_{2} \mathrm{O}$ emission factor used by KOBIZE $\left(0.58 \mathrm{~kg} \cdot \mathrm{yr}^{-1} \cdot \mathrm{LU}^{-1}\right)$ in 2013 [43]. National $\mathrm{NH}_{3}$ emissions were calculated on the basis of theoretical factors calculated by Pietrzak [44], which is $21 \mathrm{~kg} \cdot \mathrm{yr}^{-1} \cdot \mathrm{LU}^{-1}$ for dairy cows. The $\mathrm{NH}_{3}$ emission factor in this study $\left(6.9 \pm 3.9 \mathrm{~kg} \cdot \mathrm{yr}^{-1} \cdot \mathrm{LU}^{-1}\right)$ was $67 \%$ lower than that used by KOBIZE [18].

\section{Conclusions}

The following conclusions have been formulated upon our pilot research:

- There were differences in gas concentrations and the gas emission factors between studied barns $(\mathrm{p} \leq 0.05)$, which may be due to different housing and manure removal systems, ventilation rates, and diet.

- Mean values of greenhouse gases and ammonia emission factors were: $135 \pm 47 \mathrm{~kg} \cdot \mathrm{yr}^{-1} \cdot \mathrm{cow}^{-1}$ $\left(103.4 \pm 35.9 \mathrm{~kg} \cdot \mathrm{yr}^{-1} \cdot \mathrm{LU}^{-1}\right)$ for $\mathrm{CH}_{4}, \quad 0.91 \pm 0.74$ $\mathrm{kg} \cdot \mathrm{yr}^{-1} \cdot \mathrm{cow}^{-1}\left(0.70 \pm 0.57 \mathrm{~kg} \cdot \mathrm{yr}^{-1} \cdot \mathrm{LU}^{-1}\right)$ for $\mathrm{N}_{2} \mathrm{O}$, and $8.9 \pm 5.2 \mathrm{~kg} \cdot \mathrm{yr}^{-1} \cdot \mathrm{cow}^{-1}\left(6.9 \pm 3.9 \mathrm{~kg} \cdot \mathrm{yr}^{-1} \cdot \mathrm{LU}^{-1}\right)$ for $\mathrm{NH}_{3}$.

- The converted on $1 \mathrm{LU}$ (livestock unit $=500 \mathrm{~kg}$ ), $\mathrm{CH}_{4}, \mathrm{~N}_{2} \mathrm{O}$, and $\mathrm{NH}_{3}$ emission factors differed from factors used by the National Centre for Emission Management. Calculated emission factors were 20\% lower, 21\% higher, and 67\% lower, respectively.

The results of our pilot study confirm the desirability of research for determining greenhouse gases and ammonia emission factors during experiments in production 
conditions. However, they require a greater number of measuring days in one building and increasing the number of research barns. On the basis of a common methodology, the studies should be conducted across the entire country in order to take into account the structure of dairy cattle farming.

\section{References}

1. MONTENY G.J., BANNINK A., CHADWICK D. Greenhouse gas abatement strategies for animal husbandry. Agriculture, Ecosystems and Environment 112, 163, 2006.

2. STEINFELD H., WASSENAAR T. The role of livestock production in carbon and nitrogen cycles. Annual Review of Environment and Resource 32, 15.1-15.24, 2007.

3. DAI X-R., SAHA C.K., NI J-Q., HEBER A.J., BLANESVIDAL V., DUNN J.L. Characteristics of pollutant gas releases from swine, dairy, beef, and layer manure, and municipal wastewater. Water Research 76, 110, 2015.

4. PHILIPPE F.X., CABARAUX J.F, NICKS B. Ammonia emissions from pig houses: Influencing factors and mitigation techniques. Agriculture, Ecosystems and Environment 141, 245, 2011.

5. RZEŹNIK W., MIELCAREK P., JUGOWAR J.L. The emission of odor from livestock buildings for dairy cattle in Poland. Applied Engineering in Agriculture 30 (6), 961, 2014.

6. GÜRLÜK S., UZEL G., TURAN Ö. Impacts of Cattle and Sheep Husbandry on Global Greenhouse Gas Emissions: A Time Series Analysis for Central European Countries. Polish Journal of Environmental Studies 24 (1), 93, 2015.

7. SEGUIN B., ARROUAYS D., BALESDENT J., SOUSSANA J-F., BONDEAU A., SMITH P., ZAEHLE S., DE NOBLET N., VIOVY N. Moderating the impact of agriculture on climate. Agricultural and Forest Meteorology 142, 278, 2007.

8. MARCINKOWSKI T. The emission of gaseous nitrogen compounds from agriculture. Woda Środowisko Obszary Wiejskie 31 (3), 175, 2010 [In Polish].

9. SNYDER C.S., DAVIDSON E.A., SMITH P., VENTEREA R.T. Agriculture: sustainable crop and animal production to help mitigate nitrous oxide emissions. Current Opinion in Environmental Sustainability 9-10, 4, 2014.

10. BLEIZGYS R., BALEŽENTIENĖ L. Assessments of Biogenic Gas Emission Processes in Cowsheds. Polish Journal of Environmental Studies 23 (4), 1107, 2014.

11. BOBBINK R., HORNUNG M., ROELOFS J. The effects of air-borne nitrogen pollutants on species diversity in natural and semi-natural European vegetation. Journal of Ecology 86 (5), 717, 1998.

12. KUCZYŃSKI T. Ammonia emission form livestock buildings and environment. RWN-T, Zielona Góra. ISBN: 83-89044-15-3, 242, 2002 [In Polish].

13. SCHUURKES J., MOSELLO R. The role of external ammonium inputs in freshwater acidification. Aquatic Sciences - Research Across Boundaries 50 (1), 71, 1988.

14. IPCC. Climate Change: The Physical Science Basis. Contribution of Working Group I to the Fourth Assessment Report of the Intergovernmental Panel on Climate Change. Cambridge University Press, Cambridge, United Kingdom/ New York, NY, USA. Available at: http://www.ipcc.ch/ ipccreports/ar4-wg1.htm, 2007.

15. PEREIRA J., FANGUEIRO D., MISSELBROOK T.H., CHADWICK D.R., COUTINHO J., TRINDADE H.
Ammonia and greenhouse gas emissions from slatted and solid floors in dairy cattle houses: A scale model study. Biosystems Engineering 109 (2), 148, 2011.

16. FAO. Livestock Long Shadow: Environmental Issues and Options. Roma. ISBN: 978-92-105571-7, 26, 2006.

17. KOBIZE. Poland's national inventory report 2015. Greenhouse gas inventory 1988-2013. Warszawa, 2015.

18. KOBIZE. National emission balance of $\mathrm{SO}_{2}, \mathrm{NO}_{\mathrm{X}}, \mathrm{CO}$, $\mathrm{NH}_{3}, \mathrm{NMLZO}$, particulate matter, heavy metals and TZO in SNAP and NFR classification. Basic report. Warszawa, 2015 [In Polish].

19. MIELCAREK P. Verification of emission coefficients of ammonia and greenhouse gases from livestock production. Inżynieria Rolnicza 139 (4), 267, 2012 [In Polish].

20. NGWABIE N.M., JEPPSSON K.-H., NIMMERMARK S., SWENSSON C., GUSTAFSSON G. Multi-location measurements of greenhouse gases and emission rates of methane and ammonia from a naturally-ventilated barn for dairy cows. Biosystems Engineering 103, 68, 2009.

21. JOO H.S., NDEGWA P.M., HEBER A.J., NI J.-Q. BOGAN B.W., RAMIREZ-DORRONSORO J.C., CORTUS E. Greenhouse gas emissions from naturally ventilated freestall dairy barns. Atmospheric Environment 102, 384, 2015.

22. HAMILTON S.W., DEPETERS E.J., MCGARVEY J.A., LATHROP J., MITLOEHNER F.M. Greenhouse gas, animal performance, and bacterial population structure responses to dietary monensin fed to dairy cows. Journal of Environmental Quality 39, 106, 2010.

23. WALCZAK J., SZEWCZYK A., PAJĄK T., RADECKI P., MAZUR D. Methane emission from different dairy cattle housing systems. Roczniki Naukowe Zootechniki 35,(2), 187, 2008 [In Polish].

24. CORTUS E.L., JACOBSON L.D., HETCHLER B.P., HEBER A.J., BOGAN B.W. Methane and nitrous oxide analyzer comparison and emissions from dairy freestall barns with manure flushing and scraping. Atmospheric Environment 100, 57, 2015.

25. KINSMAN R., SAUER F.D., JACKSON H.A., WOLYNETZ M.S. Methane and carbon dioxide emissions from dairy cows in full lactation monitored over a six-month period. Journal of Dairy Science 78, 2760, 1995.

26. LEYTEM A.B., DUNGAN R.S., BJORNEBERG D.L., KOEHN A.C. Emissions of ammonia, methane, carbon dioxide and nitrous oxide from dairy cattle housing and manure management systems. Journal of Environmental Quality 40 (5), 1383, 2010.

27. MOSQUERA J., HOL J.M.G., MONTENY G.J. Gaseous emissions from a deep litter farming system for dairy cattle. International Congress Series 1293, 291, 2006.

28. SNEATH R.W., PHILLIPS V.R., DEMMERS T.G.M., BURGESS L.R., SHORT J.L., WELCH S.K. Long term measurements of greenhouse gas emissions from UK livestock buildings, in: Livestock Environment V: Proceedings of the Fifth International Symposium, 146, 1997.

29. CIGR. $4^{\text {th }}$ Report of working group on climatisation of animal houses: Heat and moisture production at animal and house levels. Commission Internationale du Ge'nie Rural, Horsens, Denmark, 2002.

30. BLANES V., PEDERSEN S. Ventilation Flow in Pig Houses measured and calculated by Carbon Dioxide, Moisture and Heat Balance Equations. Biosystems Engineering 92 (4), 483, 2005.

31. CALVET S., GATES R.S., ZHANG G-Q., ESTELLÉS F., OGINK N.W.M., PEDERSEN S., BERCKMANS D. Measuring gas emissions from livestock buildings: A review 
on uncertainty analysis and error sources. Biosystems Engineering 116 (3), 221, 2013.

32. ALBRIGHT L.D. Environment control for animals and Plants. USA, Michigan: ASAE. ISBN: 978-0-92935508-5, 453, 1990.

33. LINDLEY J.A., WHITAKER J.H. Agricultural buildings and structures. USA, Michigan. ASAE, ISBN: 978-0929355733, 657, 1997.

34. SNELL H.G.J., SEIPELT F., VAN DEN WEGHE H.F.A. Ventilation Rates and Gaseous Emissions from Naturally Ventilated Dairy Houses. Biosystems Engineering 56 (1), 67, 2003.

35. RONG L., LIU D., PEDERSEN E.F., ZHANG G. Effect of climate parameters on air exchange rate and ammonia and methane emissions from a hybrid ventilated dairy cow building. Energy and Buildings 82, 632, 2014.

36. NGWABIE N.M., JEPPSSON K.-H., GUSTAFSSON G., NIMMERMARK S. Effects of animal activity and air temperature on methane and ammonia emissions from a naturally ventilated building for dairy cows. Atmospheric Environment 45, 6760, 2011.

37. SCHIEFLER I. Greenhouse gas and ammonia emissions from dairy barns. $\mathrm{PhD}$ dissertation. Available at: http://hss. ulb.uni-bonn.de/2013/3450/3450.pdf, 2013.

38. SCHRADE S., ZEYER K., GYGAX L., EMMENEGGER L., HARTUNG E., KECK M. Ammonia emissions and emission factors of naturally ventilated dairy housing with solid floors and an outdoor exercise area in Switzerland. Atmospheric Environment 47, 183, 2012.

39. KARŁOWSKI J., MYCZKO R., KOŁODZIEJCZYK T., KUCZYŃSKI T. Ammonia and greenhouse gases emission factors from tie-stall dairy barn with mechanical ventilation system. Problemy Inżynierii Rolniczej 16 (1), 151, 2008 [In Polish].

40. RUMBURG B., MOUNT G.H., FILIPY J., LAMB B., WESTBERG H., YONGE D., KINCAID R., JOHNSON K. Measurement and modeling of atmospheric flux of ammonia from dairy milking cow housing. Atmospheric Environment 42, 3364, 2008.

41. KAVOLELIS B. Impact of Animal Housing Systems on Ammonia Emission Rates. Polish Journal of Environmental Studies 15 (5), 739, 2006.

42. BLUTEAU C.V., MASSÉ D.I., LEDUC R. Ammonia emission rates from dairy livestock buildings in Eastern Canada. Biosystems Engineering 103 (4), 480, 2009.

43. KOBIZE. The package of tables with data on emissions of greenhouse gases in the CRF system. Available at: http:// www.kobize.pl/pl/article/krajowa-inwentaryzacja-emisji/ id/384/gazy-cieplarniane, 2015.

44. PIETRZAK S. Inventory method for ammonia agricultural sources in Poland and its practical application. Woda Środowisko Obszary Wiejskie 16 (1), 319, 2006 [In Polish]. 